Editorial

\title{
Groundwater Quantity and Quality
}

\author{
John Luczaj \\ University of Wisconsin—Green Bay, Green Bay, WI 54311, USA; luczajj@uwgb.edu; Tel.: +1-920-465-5139 \\ Academic Editor: Damien Giurco \\ Received: 29 December 2015 ; Accepted: 25 January 2016 ; Published: 5 February 2016
}

\begin{abstract}
The world's population is facing a water crisis, which is expected to worsen dramatically during the 21st century. Problems due to over exploitation of groundwater, as well as from natural and anthropogenic contamination are major challenges facing humanity. This Special Issue contributes a selection of topics on groundwater quantity and quality issues that face different parts of the world.
\end{abstract}

Keywords: groundwater; quality; quantity; contamination; challenges; irrigation; drinking water

\section{Introduction}

Groundwater plays an important role in supplying water to much of the global population for use in agriculture, drinking water, and industrial purposes. Physical and/or economic water scarcity occurs on all of the populated continents [1], with some parts of the world facing a genuine water crisis e.g., [2,3]. Water quality problems are both natural and anthropogenic in nature, with emerging contaminants playing an increasing role [1]. Groundwater quantity and quality problems constitute a major set of challenges facing the world during this century.

This Special Issue on Groundwater Quantity and Quality contains a broad selection of eleven articles addressing several different aspects of groundwater quantity and quality. The research articles cover many different geographic regions of the world (Table 1) and include examples from both developed and developing nations. Research articles were selected after a rigorous peer-review process.

Table 1. Geographic locations addressed by articles in this Special Issue.

\begin{tabular}{ccc}
\hline Geographic Region & Topic & References \\
\hline Pakistan & Management in Mega-Irrigation Systems & {$[4]$} \\
Jordan & Over Exploitation & {$[5]$} \\
Northwestern U.S.A. & Sustained Drought & {$[6]$} \\
Germany & Groundwater Abstraction; Low-Flow Impact & {$[7]$} \\
Texas, New Mexico, U.S.A. & Case Study of Legal Issues & {$[8]$} \\
Wisconsin, U.S.A. & Groundwater Quality in Karst & {$[9]$} \\
Finland & Groundwater Quality in Public Wells & {$[10]$} \\
Mt. Etna, Italy & Groundwater Quality in a Volcanic System & {$[11]$} \\
Texas, U.S.A. & Energy-Water Nexus & {$[12,13]$} \\
Wisconsin, U.S.A. & Groundwater Issues in a Water-Rich Region & {$[14]^{1}$} \\
\hline
\end{tabular}

\section{Contributions}

The selected papers contained in this Special Issue are described in this section. They fall broadly into three categories: those focused on groundwater quantity, management, legal issues, and over exploitation (five papers); those focused primarily on groundwater quality (three papers); and those focused on the intersection of water resources and renewable energy (two papers). An additional 
review article provides insight into both quantity and quality challenges facing a water-rich region of the world in the Great Lakes region of United States of America.

\subsection{Groundwater Quantity, Management, Legal Issues, and Over Exploitation}

Five articles [4-8] examine various aspects of groundwater quantity by addressing groundwater management, legal issues, and over exploitation of groundwater.

The article by van Steenbergen et al. [4] presents a regional overview of water issues in the Lower Indus region of Pakistan. They describe the need for updated policies and conjunctive management of surface water and groundwater resources in an area with limited groundwater usage. This need arises for several reasons including the need to reduce waterlogging, increase crop yields, protecting public health, and to improve drinking water conditions in areas with saline groundwater. They supply rationale for reallocating water resources and improving water management policies to more efficiently meet the water requirements of agriculture, domestic, and industrial needs.

A contribution by Al-Zyoud et al. [5] provides an updated status of the water crisis in Jordan by illustrating the continued over exploitation of groundwater resources in the Amman Zarqa Basin that has occurred since the 1960s. They list new data about groundwater levels for the past 15 years for wells in the basin, along with an evaluation of GRACE satellite data. The results add to a growing body of evidence that the groundwater resources in the basin are not being used at a sustainable rate, and that significant policy changes are needed to secure enough water resources for future generations.

Piersol and Sprenke [6] illustrate the use of geophysical data and numerical groundwater modeling to better understand aquifer recharge pathways and to predict aquifer water levels. Their study area focused on a portion of the Palouse basin in a semi-arid region of the northwestern continental United States, which is located in the Columbia River Basalt Group and is an important source of water throughout much of the Pacific Northwest region. The article furnishes a better understanding of parts of the aquifer system that should lead to improved groundwater models and management in times of sustained drought.

Wittenberg [7] delivers a multiple regression analysis of how groundwater abstraction for irrigation has impacted low flows of the Ilmenau River in northern Germany. Distinguishing and quantifying the influence of climatic and anthropogenic variables such as precipitation, temperature, and groundwater withdrawal on annual low flows shows that groundwater abstraction for irrigation accounted for an average decrease of low flows of about 25 percent over the past 50 years. The decline of groundwater levels and decreasing low flow conditions have been influenced by the cumulative effect of higher irrigation during drier years.

An article by Wheat [8] contributes a case study of legal issues regarding water apportionment in Texas and New Mexico (United States). At the center of the analysis is a case currently before the U.S. Supreme Court, Texas v. New Mexico and Colorado (2013) [15]. The article examines the case involving the Rio Grande Compact and each state's legal obligations for managing and sharing water of the Lower Rio Grande, along with potential impacts of a Supreme Court decision. Texas claims that New Mexico is violating both the Compact and Rio Grande Project Act by using water in excess of its apportionment through its allowance of diversions of surface water and groundwater. The water quantity issues in the region are a major issue due to combined population growth on both sides of the Mexico-United States border, severe drought projections, and increased water demand.

\subsection{Groundwater Quality}

Three articles [9-11] focused primarily on groundwater quality issues. They were from three distinctly different geographic regions in different geologic settings.

The article by Erb et al. [9] focuses on a karst aquifer setting in the Western Great Lakes region of North America. The central issue of their paper was an analysis of the effectiveness of implementing recommendations of a regional "Karst Task Force" report on improving groundwater quality in the region. Four counties were analyzed for changes in water quality (e.g., brown water incidents, 
detections of bacteria) by comparing years before and after the 2007 report. The two counties in the study that adopted winter manure spreading restrictions on frozen or snow-covered ground showed statistically significant reductions in the instances of BWIs and other well water quality problems. The counties that only promoted education and training, but lacked regulatory action, showed no changes.

An article by Pitkänen et al. [10] examines the microbiological and chemical water quality of drinking water in 20 small water supply wells in Finland. They analyzed for enteric pathogens (i.e., Giardia, Cryptosporidium, Campylobacter, noroviruses) and various indicator microbes. Detection of some fecal indicator bacteria and enteric pathogens, including Giardia, has revealed a surface water interaction in some of the wells. Their study is significant because most water supplies in the country distribute drinking water without disinfection treatment.

The article by Bellia et al. [11] provides a thorough geochemical and isotopic description of a groundwater system in at Mt. Etna Volcano (Sicily, Italy) to better define the groundwater characteristics of its aquifers. Their study found that the geochemical composition varied in parts of the volcano, with most of the groundwater being the $\mathrm{Na}-\mathrm{Mg} \pm \mathrm{Ca}-\mathrm{HCO}_{3}{ }^{-} \pm\left(\mathrm{SO}_{4}{ }^{2-}\right.$ or $\left.\mathrm{Cl}^{-}\right)$type. Precipitation is the dominant source of recharge to the aquifers, although seawater mixing is important in coastal areas. Diffusion of gases appears controlled by tectonic structures in the volcano, and the ascent of deep brines also plays a role.

\subsection{The Energy-Water Nexus}

A pair of articles [12,13] involve the "Energy-Water Nexus" and its application to desalination of brackish groundwater resources.

First, the article by Kjellsson and Webber [12] presents an analysis of the potential for desalinating brackish groundwater using solar energy in Texas, United States. The analysis involves both geographic and depth distributions of brackish waters, along with solar radiation data, to determine the locations with best potential for integrating solar energy with brackish water desalination. Their results predicted that the northwestern region of Texas has the best potential for this application.

The article by Gold and Webber [13] involved a model using both wind and solar energy for reverse-osmosis desalination of brackish groundwater. They analyzed four different power generation models and presented cost analyses for an integrated model using wind and solar energy as part of a grid-connected desalination facility. Their results show that integrating desalination with renewable power can significantly reduce operational costs of water treatment.

\subsection{Review Article and Insights from a Water-Rich Region}

Also included in this issue is a review article describing the groundwater quantity and quality issues facing a water-rich part of the world in the western Great Lakes region of the United States [14]. Luczaj and Masarik present a comprehensive overview of this topic for the state of Wisconsin. Despite the fact that the region contains some of the world's most abundant surface and groundwater supplies, residents of this state face some significant groundwater quantity and quality challenges. Over exploitation of both confined and unconfined aquifers have led to significant drawdown in some areas, with unconfined aquifer drawdown affecting surface water resources. Water quality concerns are generally a more significant problem, but vary in origin and severity throughout the state. Naturally occurring contaminants include radium, arsenic and associated heavy metals, fluoride, strontium, and others. Anthropogenic contaminants include nitrate, bacteria, viruses, etc. The broad coverage of groundwater quantity and quality issues in the article will allow it to serve as a solid foundation reference for researchers in the region.

\section{Conclusions}

Eleven articles have been selected for this Special Issue. The contributions provide timely assessments of a wide variety of groundwater related problems over a broad geographic range. 
The coalition of papers should contribute significantly to the fields of groundwater quality and groundwater quantity research.

Acknowledgments: The author of this paper wishes to thank the coeditor of this special issue, the journal editors, and the authors for submitting manuscripts for publication. Referees and editors provided valuable judgment and feedback on the manuscripts, which allowed for substantial improvement in quality in some cases, and rejection of unsuitable manuscripts in other cases.

Conflicts of Interest: The author declares no conflict of interest.

\section{References}

1. United Nations Department of Economic and Social Affairs. International Decade for Action. "Water for Life" 2005-2015. Available online: http://www.un.org/waterforlifedecade/scarcity.shtml (accessed on 16 December 2015).

2. USA Today-Pumped Dry: The Global Crisis of Vanishing Groundwater. Available online: http://www.usatoday.com/pages/interactives/groundwater/ (accessed on 16 December 2015).

3. Bigas, H. The Global Water Crisis: Addressing an Urgent Security Issue; Papers for the InterAction Council, 2011-2012. UNU-INWEH: Hamilton, Canada, 2012. Available online: http://inweh.unu.edu/wp-content/ uploads/2013/05/WaterSecurity_The-Global-Water-Crisis.pdf (accessed on 16 December 2015).

4. Van Steenbergen, F.; Basharat, M.; Lashari, B.K. Key Challenges and Opportunities for Conjunctive Management of Surface and Groundwater in Mega-Irrigation Systems: Lower Indus, Pakistan. Resources 2015, 4, 831-856. [CrossRef]

5. Al-Zyoud, S.; Rühaak, W.; Forootan, E.; Sass, I. Over Exploitation of Groundwater in the Centre of Amman Zarqa Basin—Jordan: Evaluation of Well Data and GRACE Satellite Observations. Resources 2015, 4, 819-830. [CrossRef]

6. Piersol, M.W.; Sprenke, K.F. A Columbia River Basalt Group Aquifer in Sustained Drought: Insight from Geophysical Methods. Resources 2015, 4, 577-596. [CrossRef]

7. Wittenberg, H. Groundwater Abstraction for Irrigation and Its Impacts on Low Flows in a Watershed in Northwest Germany. Resources 2015, 4, 566-576. [CrossRef]

8. Wheat, E. Groundwater Challenges of the Lower Rio Grande: A Case Study of Legal Issues in Texas and New Mexico. Resources 2015, 4, 172-184. [CrossRef]

9. Erb, K.; Ronk, E.; Koundinya, V.; Luczaj, J. Groundwater Quality Changes in a Karst Aquifer of Northeastern Wisconsin, USA: Reduction of Brown Water Incidence and Bacterial Contamination Resulting from Implementation of Regional Task Force Recommendations. Resources 2015, 4, 655-672. [CrossRef]

10. Pitkänen, T.; Juselius, T.; Isomäki, E.; Miettinen, I.T.; Valve, M.; Kivimäki, A.; Lahti, K.; Hänninen, M. Drinking Water Quality and Occurrence of Giardia in Finnish Small Groundwater Supplies. Resources 2015, 4, 637-654. [CrossRef]

11. Bellia, C.; Gallardo, A.H.; Yasuhara, M.; Kazahaya, K. Geochemical Characterization of Groundwater in a Volcanic System. Resources 2015, 4, 358-377. [CrossRef]

12. Kjellsson, J.B.; Webber, M.E. The Energy-Water Nexus: Spatially-Resolved Analysis of the Potential for Desalinating Brackish Groundwater by Use of Solar Energy. Resources 2015, 4, 476-489. [CrossRef]

13. Gold, G.M.; Webber, M.E. The Energy-Water Nexus: An Analysis and Comparison of Various Configurations Integrating Desalination with Renewable Power. Resources 2015, 4, 227-276. [CrossRef]

14. Luczaj, J.; Masarik, K. Groundwater Quantity and Quality Issues in a Water-Rich Region: Examples from Wisconsin, USA. Resources 2015, 4, 323-357. [CrossRef]

15. Texas $v$. New Mexico and Colorado. Available online: www.scotusblog.com/case-files/cases/texas-v-newmexico-and-colorado (accessed on 29 January 2016). 